\title{
obituaries
}

columns

\section{Dr Robin Trevor Pinto}

Formerly Consultant Psychiatrist, Bedfordshire and Luton PartnershipTrust

Robin was born in India on 20 October 1939 into a cultured family: his mother was a professor of English and his father was an army medical officer.

Robin qualified in medicine at the Medical School of Jabalpur, Madyha Pradesh, India, in 1961 winning the Gold Medal. In the UK, he achieved further academic successes: the LMSSA, 1967; MPhil London, 1970; FRCP (Glasgow) 1970; and FRCPsych, 1978.

Robin arrived in Britain in 1965 full of self-confidence, after a glittering student career. Flirting briefly with a career in cardiology, he found his passion and niche in psychiatry, undergoing specialist training at the Maudsley. He became a consultant at the early age of 31 and dedicated his life to the care of patients in the health service, which he loved. He was always a general psychiatrist but his interests also included forensic psychiatry, eating disorders and prison work: his innovations in intensive and secure unit psychiatry saved millions of pounds and created a global effective service.

His work ethic was recognised by his colleagues with respect and awe; for example, he suffered major burns in 1986 and returned to work after 3 days, his hands still in plastic bags.

He reluctantly took on the role of First Medical Director to the Trust, which he typically fulfilled to an exemplary standard, but in recent years, he was frustrated at changes in service provision, which he felt were counter to patient care.

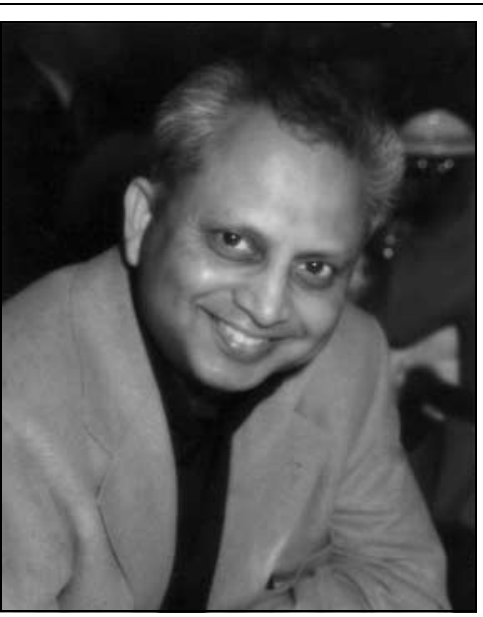

Later, he enjoyed a role within the Criminal Injury Compensation Board where he jousted with Cherie Blair in her barrister role and was rewarded with an invitation to Downing Street to share his views.

Always supremely confident in his ability, an apocryphal story of his clinical style was when, at the age of 64 , he persuaded a challenging patient in a secure unit to accept treatment by beating him in a game of badminton. The patient, a county player himself, had no idea that Robin had been in his youth a junior state champion and a national badminton finalist in India.

Robin always devoted himself to more clinical work, rather than to research or academic work, but, nevertheless, he did leave his mark on these fields also. His MPhil thesis, presented at the Institute of Psychiatry, was the first piece of research on South Asian immigrants to England and their psychiatric problems. His findings of that work still hold good today.
A job with Dr Pinto was the most highly prized assignment which could be achieved by the trainees of his Trust. Robin was a brilliant teacher, and his wardrounds were an extremely enjoyable experience. His letters which summarised complicated problems and proffered clear solutions to difficult cases, became a byword for precision and clarity.

Robin was always supportive of his junior staff and was always clearly pleased when one of the doctors he had mentored achieved some important objective in their careers. Many of these doctors became family friends of the Pintos, and would continue to rely on Robin for help and encouragement long after their training was complete.

Robin was also greatly supportive to doctors in the local community who encountered problems in their professional and in their personal lives. His view always was 'It costs nothing to help'. His clear thinking was a source of help to many, and in this way he was a great support not only to the psychiatrists of South Bedfordshire, but also to the general practitioners of the area and ultimately to the wider South Bedfordshire community.

Robin died unexpectedly from a myocardial infarction in Rome on 25 Apri 2008. At his funeral, Robin was referred to as the 'father of psychiatric services in South Beds'. His role in service provision and patient care was recognised in the renaming of his psychiatric unit as the Robin Pinto Unit in July.

Robin leaves his wife, Raynah, to whom he was completely devoted, three children and five grandchildren.

Sunil Pinto and Mark Agius

doi: 10.1192/pb.bp.109.025213

\section{Dr Richard Neil Lucas, OBE}

\section{Formerly Consultant Psychiatrist, St Ann's Hospital London, and Psychoanalyst}

Richard was born in Leeds on 2 Apri 1943. His father, a dentist, died when Richard was only 10 months old, and he was brought up in Leeds with his elder brother by his mother, an academic. When he was 10 years old, his mother remarried and the family expanded to include his stepfather's three children. Richard was very much true to his Yorkshire roots and a lifelong supporter of Leeds United football club.

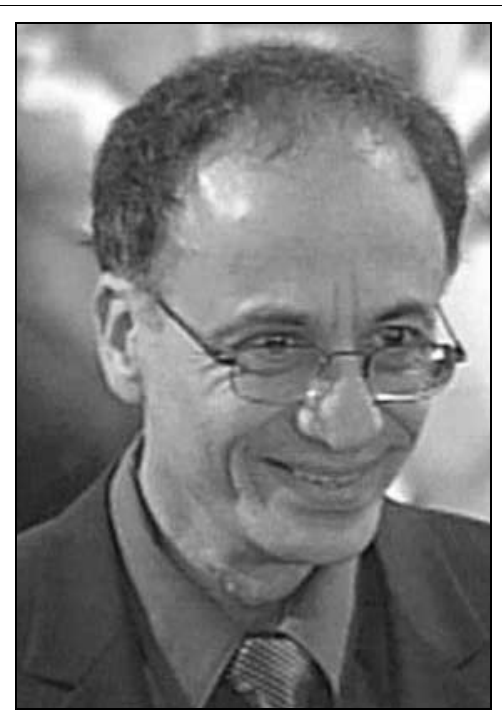

He qualified at the London Hospital, where his father and brother had studied before him, also gaining a degree in physiology and a prize in surgery. He started his psychiatry training at the Royal Free Hospital and in 1970 moved to the Maudsley Hospital.

At the age of 20, whilst a medical student, he developed a lymphoma which was treated with surgery and radiotherapy, but with his very positive view of life, he shook this off and continued his training with vigour, becoming very interested in psychoanalytic understanding, particularly in the area of psychosis, and to this end was stimulated by one of his teachers at the Maudsley, Dr Henry Rey.

In 1978 he took up a consultant psychiatrist post at the Claybury Hospital, 
Essex, by which time he had completed his psychoanalytic training. At that time he was in the unique position of being a catchment area consultant psychiatrist and practising psychoanalyst, and he brought these psychoanalytic skills and understanding to deploy them in furthering the understanding of psychotic states. The combination of his personal warmth, energy, humour and clinical skills resulted in him welding together a very loyal clinical team and his unit was renowned for being able to manage the most disturbed patients. In 1996, Claybury was closed and Richard and his ward moved to St Ann's Hospital in Tottenham, East London, with many of his team members following him to the new location.

Throughout, Richard combined his National Health Service (NHS) work with a private practice. He was a workaholic, working long hours but still had the energy and vitality to be very involved with his family.
The unique combination of skills and experience in psychiatry and psychoanalysis led to the development of very creative ideas with seminal papers on psychosis, introducing the understanding of the psychotic wavelength, and papers on puerperal and manic depressive states Richard both spoke and wrote in a vivid, engaging way and this led to him being recognised as a very talented teacher, and attachments to his unit by former trainees and honoraries were always sought after.

His energy and creative ideas led him to develop initiatives through the Psychotherapy Faculty of the Royal College of Psychiatrists of which he was an executive member and as Chair of the General Psychiatric Section of the Association of Psychoanalytic Psychotherapy of which he was a founding member. He was also active in the psychoanalytic world becoming Chair of the NHS Liaison Committee of the British Psychoanalytic Society and organised several successful conferences.
In the 1990s he developed thyroid cancer which was successfully treated, and again his positiveness came through as he overcame this and continued his work and his life with full vigour.

In addition, he was the Psychiatrist for the Disability Living Allowance Award Board and his contribution over many years was recognised by receiving the award of the OBE in 2003.

In 2007, he developed a further cancer, but again, managed to return to work after retiring from his in-patient unit and was energetically developing an assertive outreach team when he was taken suddenly ill and died on 28 July 2008 at the age of 65 .

Richard was a very committed family man, very involved with his children and had a strong relationship with his wife, with a large network of friends and family.

$\mathrm{He}$ is survived by his wife Lynne, his son Matthew, his daughter Hannah and daughter-in-law Michaela.

Tony Garelick

doi: 10.1192/pb.bp.109.025205 